\title{
Analysis of Governance and Efficiency on Zakat Distribution: Evidence From Indonesia
}

\author{
Novendi Arkham Mubtadi \\ Peradaban University \\ Dewi Susilowati \\ Jenderal Soedirman University
}

\begin{abstract}
This study analysesand identifies the governance factor(s) that influence zakat disbursement efficiency for Indonesia's National Zakat Board (BAZNAS )in four district of Central Java Province, namely Banyumas, Purbalingga, Banjarnegara, and Kebumen. This research examines how the zakat institution in Indonesia has improved in terms of disbursement activities over the past 5 years (2011-2015).This is a quantitative research study that uses two approaches of efficiency analysis, namely (i) zakat disbursement efficiency measurement (ratio analysis) and (ii) identification of governance factor(s) that influence the zakat disbursement efficiency of the zakat institutions (regression analysis). Eviews 9 was used in data calculation. In the first approach, there are three efficiency measures: disbursement efficiency, cost efficiency and time efficiency. In the second approach, governance factors (board size; professionals on board; and frequency of board meetings) identify the influence of governance factors on zakat disbursement efficiency measures. The findings showthat there is a negative influence between board size and cost efficiency and no influence with disbursement and time efficiency. However, the relationship between board size and disbursement and time efficiency is rejected because of insignificant results. Professionals on boards has a positive influence on disbursement, cost and time efficiency. Lastly, the frequency of board meetings positively influences disbursement efficiency and time efficiency. Frequency of board meetings showed a negative influence with cost efficiency. This research is significant as it could contribute to future discussions on the potential ways to improve zakat governance and efficiency in Indonesia. The outcomes from the discussions will be useful as a guide for policymakers looking to improve the zakat institution's governance system.
\end{abstract}

Keywords: Efficiency, Governance, Indonesia, Zakat

\section{INTRODUCTION}

Muslim economists argue that the Islamic economic system is built on two elements, the elimination of usury and actualization of zakat (Hafidhuddin, 2009: 85). It is based on words from Allah SWT:

"And whatever you give for interest to increase within the wealth of people will not increase with Allah. But what you give in zakah, desiring the countenance of Allah - those are the multipliers". (QS. Ar-Rum: 39)

With respect to zakat actualization, zakat is not considered a personal matter even though it is given by personal consciousness because zakat is a right and obligation of every Muslim. The main purpose of zakat is to create a balance 
between people who are over-funded and people who are under-funded (Rahayu, 2014). Zakat is expected to provide social economic justice for the community (Kahf, 1989).

Performance measurement is needed to monitor whether a company's operations are achieving its objectives (Noor et al., 2014). One indicator that must be measured is efficiency, because according to Ahmad and Ma'in (2014) efficiency represents the maximum output that can be produced based on available inputs. According to Rahman (2007), measuring efficiency is not a broad and complex process because it uses index and ratio. However, efficiency is useful for monitoring and improving organizational performance, including the Zakat Management Organization (OPZ). In OPZ, efficiency is measured by how input is transformed into output. Noor et al. (2015) state that one of the objectives of performance evaluation is to measure efficiency as a form of accountability to zakat stakeholders and obedience to Allah SWT.

Wahab and Rahman (2011) developed a framework for measuring the efficiency and governance of zakat institutions. They emphasize that the importance of evaluating efficiency and zakat governance is to enable higher rates of productivity. Wahab (2013) posits that there is a relationship between efficiency and governance.

The latest zakat management guideline was officially launched on 26 May 2016 in Turkey and was titled Zakat Core Principles (ZCP). As such, ZCP is a guide for international zakat management, extending beyond the Indonesian context. This program was initiated by the Indonesian Bank (BI) and the Indonesian National Board of Zakat (BAZNAS). In short, ZCP contains 18 core principles that discuss the efficiency of zakat. The discussion of the 18 core principles is classified into:

Table 1. Dimensions of Zakat Core Principles

\begin{tabular}{lll}
\hline No. & \multicolumn{1}{c}{ Dimensions } & \multicolumn{1}{c}{ ZCP } \\
\hline 1. & Legal Foundations & ZCP 1 - ZCP 3 \\
2. & Zakat Supervision & ZCP 4 - ZCP 6 \\
3. & Zakat Governance & ZCP 7 - ZCP 8 \\
4. & Intermediary Function (Collection and Distribution) & ZCP 9 - ZCP 10 \\
5. & Risk Management & ZCP 11 - ZCP 14 \\
6. & Shariah Governance & ZCP 15 - ZCP 18 \\
\hline
\end{tabular}

Source: Beik (2015)

This research is carried out in Central Java Province, Republic of Indonesia, and use four districts as samples, namelyBanyumas, Purbalingga, Banjarnegara, and Kebumen. While measuring zakat governance as the independent variable,this research also employs indicator from Wahab (2013) that are board size, professional on board, and frequency of board meetings.

There are differences regarding the management of zakat across some countries. Jaelani (2016) studied the differences of zakat management in
Indonesia and Brunei Darussalam. The result, in terms of efficiency, was that Brunei Darussalam is more efficient than Indonesia. This could be due to several reasons, such as better regulation and governance of OPZ in Brunei Darussalam. However, as zakat governance is not maximized, there is a problem in terms of efficiency of zakat distribution. Additionally, different management, the wider territory of Brunei Darussalam and the larger population of Indonesia are also factors for less optimal efficiency of zakat distribution in Indonesia. 
This was taken into consideration when choosing the area and subject of research (BAZNAS in 4 districts of Banyumas, Purbalingga, Banjarnegara, and Kebumen) in this study. The reason for choosing these participants is linked to the amount of zakat funds that have been collected or distributed. However, the amount of zakat funds disbursed has not reduced the percentage of poor people in each region,which is still above the average percentage of poor people in Central Java Province. This raises questions about the effectiveness and efficiency of zakat fund distribution by BAZNAS. Scholars and Muslim economists state that zakat can in fact reduce poverty so this issue is interesting to study. This is evidenced by data from the Central Bureau of Statistics (BPS) as follows:

Table 2. The Average of Poor Population in District of Banyumas, Purbalingga, Banjarnegara and Kebumen

\begin{tabular}{cccccc}
\hline Year & $\begin{array}{c}\text { The Average of } \\
\text { Poor Population } \\
\text { in Central Java } \\
\text { Province (\%) }\end{array}$ & $\begin{array}{c}\text { Banyumas } \\
(\boldsymbol{\%})\end{array}$ & $\begin{array}{c}\text { Purbalingga } \\
(\boldsymbol{\%})\end{array}$ & $\begin{array}{c}\text { Banjarnegara } \\
(\boldsymbol{\%})\end{array}$ & $\begin{array}{c}\text { Kebumen } \\
(\boldsymbol{\%})\end{array}$ \\
\hline 2011 & 16,21 & 21,11 & 23,06 & 20,38 & 24,06 \\
2012 & 14,98 & 19,44 & 21,19 & 18,87 & 22,40 \\
2013 & 14,98 & 19,44 & 21,19 & 18,87 & 22,40 \\
2014 & 13,58 & 17,45 & 19,75 & 17,77 & 20,50 \\
2015 & 13,58 & 17,52 & 19,70 & 18,37 & 20,44 \\
\hline
\end{tabular}

Source: Statistics Indonesia (2015)

The amount of APBD assistance provided by each regency varies according to their respective capabilities. Assistance from APBD is important for BAZNAS to support the operational costs that must be spent in collecting and distributing zakat funds.APBD funds are a major source of activity support so BAZNAS continuity depends on the amount of funds provided by the local government. In fact, all funds collected, according to the provisions of sharia, should be channeled this way. This becomes a big challenge and consideration for each BAZNAS related to the efficiency of channeling the collected zakat funds.

Based on the fact that previous research only highlighted some of the inefficient OPZs, and that there is limited researchon influencing factors affecting the efficiency of zakat disbursement, we are therefore interested in analyzing the influence of zakat governance to the zakat disbursement efficiency.

\section{LITERATURE REVIEW}

Ali (2015) describes accountability in the zakat perspective into two parts, consisting of primary accountability (responsibility to Allah SWT), and secondary accountability (responsibility to society). This concept is adapted from Mustaffha (2007) as follows: 


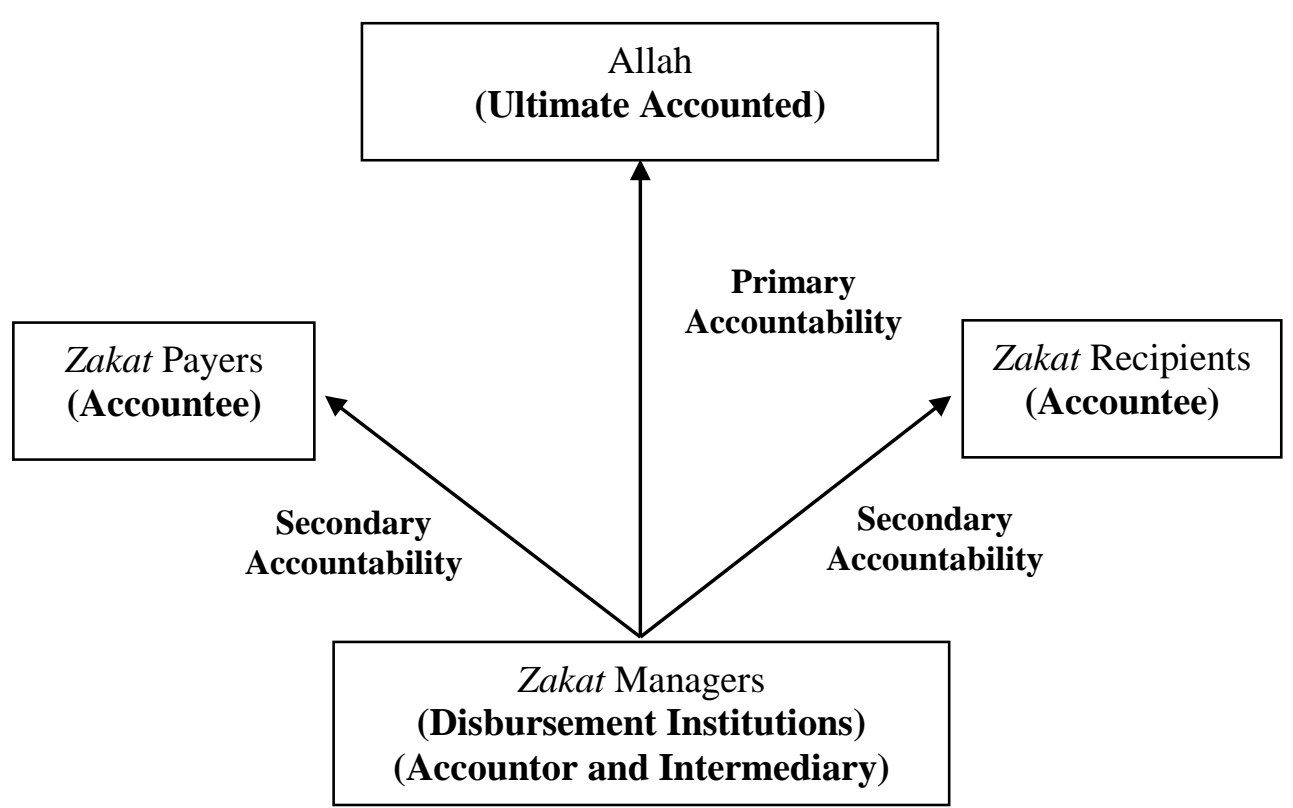

Figure 1. The Concept of Accountability That Underlying Zakat Disbursement Management by Zakat Institutions

Accountability is ensured through the presentation of accountable and transparent statements of zakat. Such reports are often a part of a strategy to increase accountability and transparency, so trust will arise from muzakki and stakeholders (Nikmatuniayah and Marliyati, 2015). Allah SWT says:

"Take, [O, Muhammad], from their wealth a charity by which you purify them and cause them increase, and invoke [ Allah 's blessings] upon them. Indeed, your invocations are reassurance for them. And Allah is Hearing and Knowing”. (QS At-Taubah: 103)

This verse explains that zakat was taken (invited) from the people who were obliged to pay zakat (muzakki) to be given to those who deserve it (mustahiq). Imam al-Qurthubi when interpreting the verse, explains that those who take and pick up zakat (amilin) are officers assigned by the government to take, write down, calculate, and record the zakat from muzakki and redistribute to mustahiq (Hafidhuddin, 2007: 125). Rasulullah SAW once employed a young man named Ibn Lutaibah, from the Asad tribe, to take care of the zakat of Bani Sulaim. He also sent Ali ibn Abi Thalib KW and Muadz bin Jabal to Yemen to be amil zakat. Afterwards, by the khulafaur-rasyidin they always had special officers who manage zakat, both in terms of taking and distributing. This indicates that zakat obligations are not merely charitable, but also an authoritative obligation (ijbari). Therefore, since the time of Rasulullah SAW until now, the management of zakat in almost every country is regulated by the government (Hafidhuddin, 2009: 169).

In measuring the efficiency and effectiveness of zakat management, BAZNAS and Bank Indonesia initiated the Zakat Core Principles (ZCP) concept which serve as global guidelines for zakat management. Indonesia has unique characteristics in the management of zakat. In ZCP, Indonesia embraces voluntary principles in the collection of zakat funds. Both government agencies and nongovernment agencies can perform collection, management and functions. Unlike the countries in the Middle East, Saudi Arabia, Sudan, Libya, Yemen, Kuwait, and Pakistan, which are 
mandatory and fully managed by the following table: government. This is represented in the

Table 3. Characteristic of Zakat Management Scheme in Various Country

\begin{tabular}{cll}
\hline & \multicolumn{1}{c}{ Character of collection } \\
\cline { 2 - 3 } Full Government & \multicolumn{1}{c}{ Compulsory } & \multicolumn{1}{c}{ Voluntary } \\
& $\begin{array}{l}\text { Saudi Arabia, Pakistan, } \\
\text { Kuwait, Yemen, } \\
\text { Sudan, Libya }\end{array}$ & $\begin{array}{l}\text { Bangladesh, Bahrain, } \\
\text { Indonesia, Jordan }\end{array}$ \\
$\begin{array}{c}\text { Goverment linked } \\
\text { institution } \\
\text { (Corporation) } \\
\text { NGO }\end{array}$ & Malaysia & Singapore, Egypt \\
& & Algeria, Indonesia, South \\
& & Africa \\
\hline Beik et al. (2014)
\end{tabular}

Source: Beik et al. (2014)

Rahman (2007) explains a purpose of measuring the level of efficiency of zakat institutions is to assess the proportion of zakat distribution to the number of beneficiaries. Wahab and Rahman (2011) state that the most important aspect in measuring efficiency is understanding the input and output variables used. Mustaffha (2007) provides one example of input and output measurement through the study on the distribution of zakat in Malaysia as listed in the following table:

Table 4. The Input, Process, and Output Used in Zakat Disbursement Efficiency

\begin{tabular}{lll}
\hline \multicolumn{1}{c}{ Input } & \multicolumn{1}{c}{ Processes } & \multicolumn{1}{c}{ Output } \\
\hline Zakat Collection & Disbursement Efficiency & Zakat Disbursement \\
Zakat Cost & Cost Efficiency & Zakat Disbursement \\
Time & Time Efficiency & Zakat Recipient \\
Source: Mustaffha (2007) & &
\end{tabular}

In summation, zakat institutions should focus on how the distribution of zakat can be effective through a series of programs that have been prepared, instead of solely focusing on the origin of the spent funds (Laela, 2010). In this study, efficiency will be measured based on the framework of Mustaffha (2007) and Beik et al. (2014), that is, disbursement efficiency, cost efficiency, and time efficiency.These three measures are illustrated in Figure 2 below:

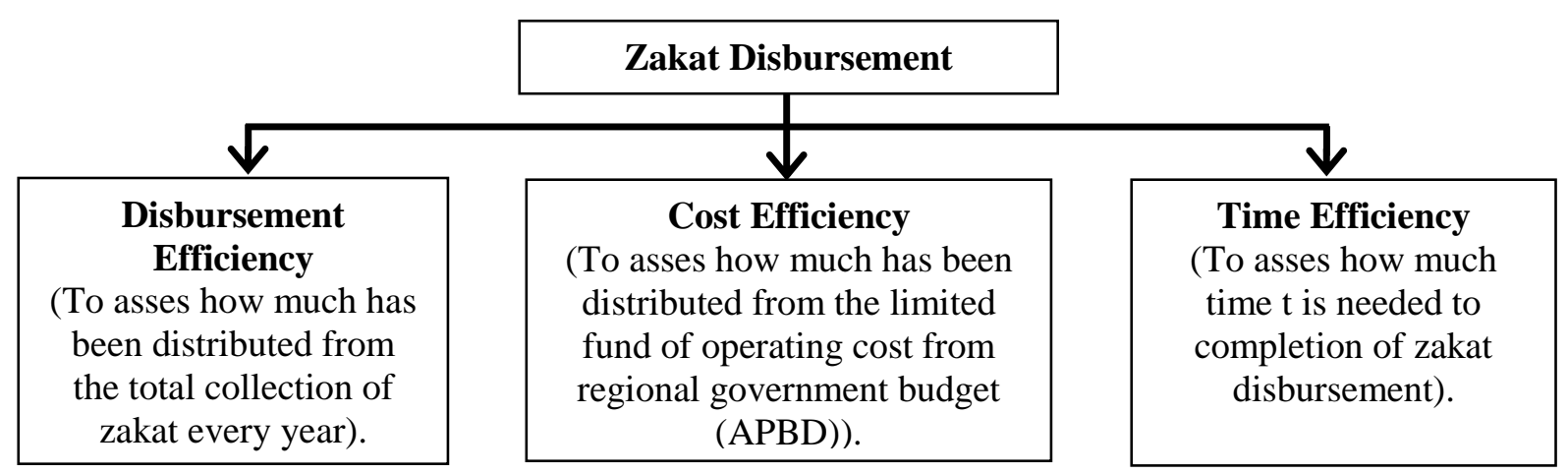

Source: Mustaffha (2007)

Figure 2. Zakat Disbursement Efficiency (ZDE Measures) 
Beik (2015) describes the definition of zakat governance as follows:

"Zakat Governance is the backbone of zakat regulations as it is detrimental to ensure zakat activities operates in accordance to Islamic virtues and domestic legal act and zakat regulatory framework".

Zakat governance derives from the development of corporate governance. The fiqh rules used in zakat governance are likulli maqamun maqalun wa likulli maqalun maqamun (every place hasits word and every word has its place). This rule is also used in making sharia banking terms, sharia insurance, sharia tourism, sharia accounting, sharia stock market, sharia hedging, sharia letters of credit, sharia governance and others. Zakat governance indicators in this study will be measured based on the framework of Wahab (2013) that consider board size, professional on board, and frequency of board meetings.

Therefore, based on literature review, the concept of accountability adapted from Ali (2015) can be expanded upon, as reflected in Figure 3 below:

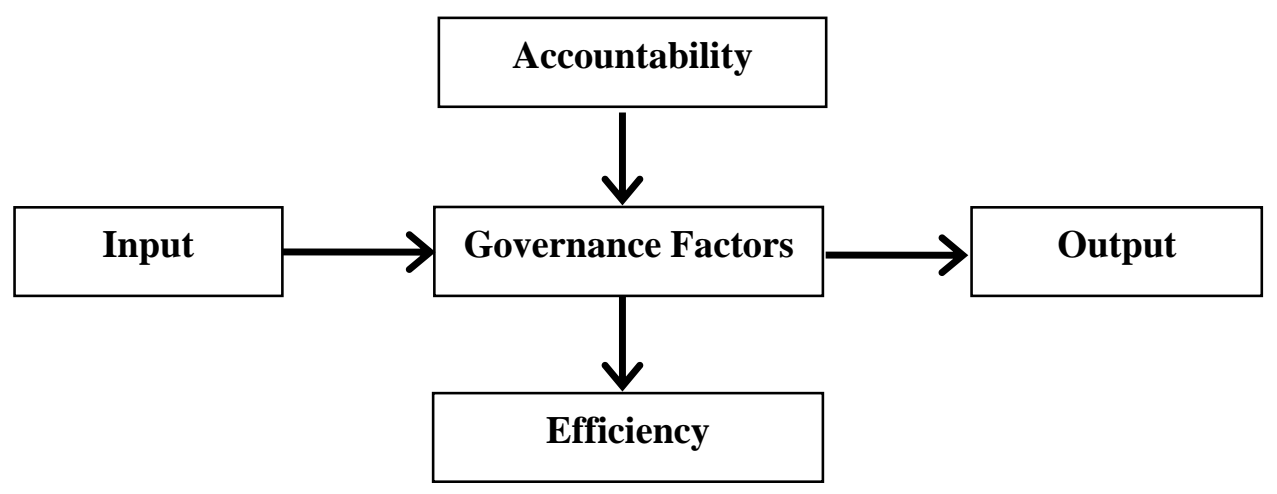

Figure 3. The Concept of Accountability in Zakat Institutions

\section{RESEARCH METHODOLOGY}

\section{Sample}

The sample is part of a carefully chosen target population (Sekaran, 2003: 266). Sample selection method derived from the population sampling technique. This method takes the entire population as a sample. This study took the population and sample of all BAZNAS in 4 districts all located in Central Java Province, that is:

1. BAZNAS District of Banyumas

2. BAZNAS District of Purbalingga

3. BAZNAS District of Banjarnegara

4. BAZNAS District of Kebumen

This research sampled financial statement data for 2011-2015. Year 2011 was chosen because it was the year that
Law no. 23 of 2011 on the management of zakat was launched, which was expected to improve overall zakat management.

\section{Data}

The data taken is annual data. The data used in this research is panel data. Panel data is data collected from multiple subjects over a period of time. This panel data is a combination of time series data and cross section data. Time series data is collected from time to time on one subject, while cross section data collected from several objects at one time (Suliyanto, 2011: 229). The total unit of analysis to be tested is 20 , which is calculated by multiplying 4 cross section data by 5 time series data.In this study, the researcher has identified three dependent variables and three independent variables used in the 
multiple regressions. These two tables independent variables respectively.

(Tables 5 and 6) list the dependent and

Table 5. Dependent Variables for Zakat Disbursement Efficiency

\begin{tabular}{|c|c|c|}
\hline $\begin{array}{l}\text { Dependent } \\
\text { Variables }\end{array}$ & Definition of The Dependent Variables & Formula \\
\hline $\begin{array}{l}\text { Disbursement } \\
\text { Efficiency }\end{array}$ & $\begin{array}{l}\text { Disbursement efficiencyderived fromratio } \\
\text { analysis thatis ratio of thetotalzakat } \\
\text { disbursement to thetotal zakatcollection. }\end{array}$ & $\frac{\text { Total ZakatDisbursement }}{\text { Total ZakatCollection }}$ \\
\hline Cost Efficiency & $\begin{array}{l}\text { Cost efficiencyderived from the ratio of } \\
\text { thetotaldisbursement to the zakat disbursement } \\
\text { relatedcosts from regional government budget } \\
\text { (APBD). }\end{array}$ & $\frac{\text { Total ZakatDisbursement }}{\text { Total Distribution Cost }}$ \\
\hline Time Efficiency & $\begin{array}{l}\text { Time efficiencythat is number of zakat } \\
\text { disbursement in one year (month). }\end{array}$ & $\frac{12}{\text { Times Zakat Disbursement }}$ \\
\hline
\end{tabular}

Table 6. Independent Variables for Zakat Disbursement Efficiency

\begin{tabular}{ll}
\hline \multicolumn{1}{c}{ Independent Variable } & Measurement of theIndependentVariables \\
\hline Board Size & Number ofBoard of Directors \\
Professionals on Board & Number ofProfessionals on Board \\
FrequencyofBoard Meetings & Number ofMeetings PerYear \\
\hline$e:$ Wahab (2013) &
\end{tabular}

Source: Wahab (2013)

The hypothesis test demonstrates the level of influence of one individual explanatory/independent variable in explaining the variation of the dependent variable.Software that was used in analysing hypothesis is Eviews 9.

The criterion of acceptance test of $\mathrm{Ha}$ is determined by comparing probability value with significance level. If the result is prob. significant at $\alpha=1 \%$ or $5 \%$ or $10 \%$ and show a direction coefficient according to each hypothesis, the alternative hypothesis accepted (Widarjono,2016: 65).

\section{RESULT AND DISCUSSION}

Result

Descriptive analysis and inferential statistics analysis consisting of ratio and regression analyses, will inform the analysis presented. The results will be discussed in two parts. The first will take the form of Table 7 that lays out the summary of the data including mean, minimum, maximum andstandard deviation .Secondly, Table 8 will outline hypothesis testing that summarises the multiple regression results together with the expected sign of the hypotheses discussed earlier. Based on the standardised beta coefficient $(\beta)$ seven out of the nine hypotheses were accepted and the remaining two were rejected. 
Table7. Descriptive Statistics of Dependent and Independent Variables

\begin{tabular}{lrrrrr}
\hline & N & Minimum & Maximum & Average & $\begin{array}{c}\text { Standard } \\
\text { Deviation }\end{array}$ \\
\hline Disbursement Efficiency (Y1) & 20 & 0,64 & 0,96 & 0,81 & 0,09 \\
Cost Efficiency (Y2) & 20 & 0,01 & 0,12 & 0,05 & 0,02 \\
Time Efficiency (Y3) & 20 & 2 & 6 & 3,75 & 1,51 \\
Board Size (X1) & 20 & 4 & 9 & 6 & 1,45 \\
Professional on Board (X2) & 20 & 0,33 & 0,78 & 0,52 & 0,17 \\
Frequency of Board Meetings (X3) & 20 & 3 & 6 & 4 & 1,12 \\
\hline
\end{tabular}

Source: Author's Computations(2017)

Table 8. Relationship Direction for Multiple Regression

\begin{tabular}{|c|c|c|c|c|}
\hline 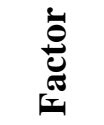 & Hyphotesis & $\begin{array}{l}\text { Exp } \\
\text { Sign }\end{array}$ & $\begin{array}{l}\text { Regression } \\
\text { Result }\end{array}$ & Hyphotesis Test \\
\hline \multirow{3}{*}{ 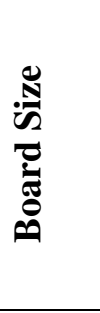 } & $\begin{array}{l}\mathrm{H}_{1} \text { : board size has a positive } \\
\text { influence todisbursement } \\
\text { efficiency }\end{array}$ & + & 0.7699 & Reject \\
\hline & $\begin{array}{l}\mathrm{H}_{2} \text { : board size has a negative } \\
\text { influence tocost efficiency }\end{array}$ & - & $0.0180 * *$ & Accept \\
\hline & $\begin{array}{l}\mathrm{H}_{3} \text { : board size has a negative } \\
\text { influence totime efficiency }\end{array}$ & - & 0.1336 & Reject \\
\hline \multirow{3}{*}{ 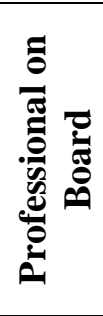 } & $\begin{array}{l}\mathrm{H}_{4}: \text { professional on } \\
\text { board has a positive influence to } \\
\text { disbursementefficiency }\end{array}$ & + & $0.0000 * * *$ & Accept \\
\hline & $\begin{array}{l}\mathrm{H}_{5}: \text { professional on board has a } \\
\text { positive influence tocost efficiency }\end{array}$ & + & $0.0547^{*}$ & Accept \\
\hline & $\begin{array}{l}\mathrm{H}_{6} \text { : professional on board has a } \\
\text { positive influence totime efficiency }\end{array}$ & + & $0.0004 * * *$ & Accept \\
\hline \multirow{3}{*}{ 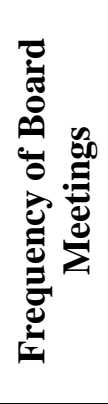 } & $\begin{array}{l}\mathrm{H}_{7} \text { : frequency of board } \\
\text { meetings has a positive influence } \\
\text { todisbursementefficiency }\end{array}$ & + & $0.0684^{*}$ & Accept \\
\hline & $\begin{array}{l}\mathrm{H}_{8} \text { : frequency of board } \\
\text { meetings has a negative influence } \\
\text { tocost efficiency }\end{array}$ & - & $0.0000 * * *$ & Accept \\
\hline & $\begin{array}{l}\mathrm{H}_{9} \text { : frequency of board } \\
\text { meetings has a positive influence } \\
\text { totime efficiency }\end{array}$ & + & $0.0000 * * *$ & Accept \\
\hline
\end{tabular}

* Significance level below 0.1

** Significance level below 0.05

*** Significance level below 0.01

\section{Discussion}

\section{Board Size and Disbursement Efficiency $\left(H_{1}\right)$}

Findings indicate that board size had no effect on disbursement efficiency. This means that the larger board size will not have any effect on the efficiency of the distribution of zakat.

This result is also supported by Doyle (2005) who stated that the zakat management organization does require multiple boards to meet the diverse range of stakeholders. Essentially, a large 
number of boards does not necessarily increase zakat distribution efficiency naturally.

In profit-based organizations, Ali et al. (2014) explained that the size of the board will only facilitate effective performance management and not affect the financial performance of the company. In addition, the possibility of conflict will increase among board members, which will disrupt the process of achieving organizational goals. Tomar and Bino (2012) similarly stated that the board size does not have any effect on efficiency.

In zakat, the results of research indicate that the organization's goal of efficiency in the distribution of zakat will not be affected by the size of the board. This is reinforced by Amara and Atia (2016). They researched zakat it Algeria and stated that the efficiency of Zakat Institutions is not determined by the size of the board but instead theorized that it is based on the board policies produced during regular meetings. Consolidation of supervision in providing and verifying accurate and integrated data and information can be realized with the size of the board.

\section{Board Size and Cost Efficiency $\left(\mathrm{H}_{2}\right)$}

This research corroborates the proposed hypothesis that board size negatively affects the cost efficiency.

Wahab (2013) in his Malaysian study found with respect to accountability, the size of the board will require more responsibility for overseeing the organization of zakat management. They will require a bigger mandate to manage the distribution of zakat to be more efficient. As a result, the size of the board will result in large additional costs. However, please note that in Malaysia, amil took almost all the zakat fund allocation set in the shari'a, which is equal to $12.5 \%$.
Similarly, in Indonesia because not all boards of Zakat are State Civil Apparatus (ASN), many come from public figures such as ustadz or kyai, so all welfare-related costs are not entirely absorbed by the state. This is considered the responsibility of the Regional Government to provide Regional Government Budget (APBD) assistance to BAZNAS. The larger the board size the higher the APBD funds are given, thus producing cost inefficiency.

This is in accordance with Hosen and Rahmawati (2016), who stated that human resources costs should be a top priority when determining what needs to be spent and what needs to be cut. In this study, the cost of human resources is influential because it is included in the operational costs and is takenfrom APBD aid, which is the main resource for managing zakat in BAZNAS. Taking zakat funds collected from muzakki will violate Islamic law which states that zakat funds exclusively belong to mustahiq.

\section{Board Size and Time Efficiency $\left(H_{3}\right)$}

The findings reject the hypothesis that board size negatively affect the time efficiency. This is in accordance with the research of Ahmad et al. (2015) who found that for mustahiq, the time required to wait for the zakat funds to be received has a relationship with satisfaction. An elongated process of channeling zakat funds to reach the mustahiq will cause deep disappointment, asthe zakat funds are important for the survival of poorer communities. Sometimes, boards do not pay attention to thisbecause they are fixated on their duty to strengthen the institution. In fact, the success of zakat distribution does not look to the size of the nominal amount of zakat funds distributed, but also the time of distribution.

Bodroastuti (2009) reinforces this by explaining that boards will indeed determine both short and long term 
policies. However, thiswill not be affected by the size of the board size. Boardswill only benefit the organization in internal conditions, not creating a network with outsiders as well as ensuring the availability of resources. This indicates that the board size has no effect on time efficiency.

Ingram (2015)states that the boards in nonprofit organizations should be accountable to all stakeholders. They are responsible for protecting organizational funds. However, the number of board members will not speed up the time of zakat distribution this range will not affect the decision on when zakat will be distributed.

\section{Professional on Board and Disbursement Efficiency $\left(\mathrm{H}_{4}\right)$}

The results of the study received the proposed hypothesis that professional on board has a positive effect on disbursement efficiency. This corroborates results from Lestari et al. (2015) who examined the organizational factors of the Zakat Management Organization (OPZ) in Banyumas District and found that amil professionalism (in terms of education and experience) is needed for distributing zakat.

Sobana et al.'s (2016) study of Cianjur, stated BAZNAS must improve knowledge in the field of technology and management, since this may increase the degree of professionalism among zakat administrators in the management of zakat funds, as well as the actualization of information systems and transparency regarding distribution of zakat funds to the society.

This is reinforced by Bodjonegoro (2016), who explained that there are two important priorities for zakat management improvements in Indonesia. Firstly, zakat distribution is still inefficient. Second, the issue of the number and competence of human resources that will channel the zakat funds to the eligible.

\section{Professional on Board and Cost Efficiency $\left(\mathrm{H}_{5}\right)$}

Findings prove the proposed hypothesis that professional on board has a positive effect on cost efficiency. This is in accordance with the research of Snowdown and Rajacich (1993), which states that full accountability will only be achieved if done by professionals. This is because they possess expert knowledge in their respective fields which will improve efficiency by reducing operational costs.

Gobel (2013) reinforces this by stating that cost efficiency is needed to reduce unnecessary expenditures, in order to avoid waste. Operational costs will be more efficient if managed by an adequate number of professionals.

\section{Professional on Board and Time Efficiency ( $\left.H_{6}\right)$}

The results show that professionals on board has a positive effect on time efficiency, just as the hypothesis is proposed.

This result is in accordance with the research of Rahman et al. (2012) who found that in Malaysia, less fortune students are welcome to apply for funding applications from zakat every year. Application submissions are almost always accepted, except when due to risk mitigation considerations. Applications received will be processed quickly because zakat institutions are handled by professional personnel.

Dohmann (2009) states that professional boards with appropriate governance mechanisms will be more accountable in designing policies and making decisions to fulfill management responsibilities to the community. 
Furthermore, they are also accountable and quick in making decisions that will improve organizational efficiency. Hsu and Petchsakulwong (2010) reinforce this by asserting that professional boards will make the best decisions faster by leveragingtheir professionalism.

\section{Frequency of Board Meetings and} Disbursement Efficiency $\left(\mathrm{H}_{7}\right)$

The results showed that the frequency of board meetings had a positive effect on the disbursement efficiency, just as the hypothesis proposed. In all the BAZNAS that were part of the sample conducted zakat distribution activities after a meeting with the board. Therefore, more frequent meetings will make the distribution of zakat more efficient.

This is supported by Khancel (2007) and Lin et al. (2009) whostates that the frequency of board meetings with many discussion activities will improve the quality of governance and improve efficiency. Vafeas (1999) also states that the increasing frequency of board meetings will improve the operational performance of an organization.

Kholis et al. (2013) states that increased number of boardmeetings can mitigate instances offraud and misuse of the zakat funds. There are two concepts of philanthropy according to them: (1) volunteerism that cannot be prosecuted from the giver, (2) philanthropy is the story of rights, the transition of resources from those who are entitled to receive.

Frequency of Board Meetings and Cost Efficiency $\left(\mathrm{H}_{8}\right)$

Findings proved the proposed hypothesis that the frequency of board meetings had a negative effect on cost efficiency or operational costs.
This is in accordance with $\mathrm{t}$ Shivdasani and Zenner (2002) who states that board meetings should not be too frequent as it will disrupt the organization's operations and is timeconsuming. There should be a balance between the costs incurred and the benefits derived from the meeting. Meetings will be a waste when there is no solution to the issues discussed, while only a single meeting has a high cost. A balance must be stricken.

This is reinforced by Khancel (2007) who believes thatboard meetings should be held at a certain time, so as not to spend too much on operational costs. Vafeas (1999) asserts that board meetings will lead to wasteful manjerial time and more expenses to be incurred such as transportation costs, consumption, and fees for board. This means that increased board meeting frequency will reflect a negative cost efficiency.

\section{Frequency of Board Meetings and Time} Efficiency $\left(H_{9}\right)$

Findings supported the proposed hypothesis that the frequency of board meetings had a positive effect on the efficiency of the time of zakat disbursement. This is in accordance with the results of Nurzaman (2010) who found that zakat funds should be distributed over a short period so that the frequency of board meetings should be held more often.

Ntim and Osei (2011) studied South Africa and confirmed thisby stating that board meetings will enhance the capacity and quality of supervision, as well as improve the financial performance of the organization, in this case the faster the zakat funds are disbursed. Additionally, Oran (2009) stated that in meetings, boards should prioritize the poor and indigent in the distribution of zakat funds because the two asnaf are eager for economic assistance to meet their needs immediately. 
Thus, if zakat funds have been collected, there is no reason to delay the distribution.

Wahab (2013) argues that the board will carry out its duties with full responsibility in meetings held to meet the terms, commitments, and total accountability. In addition, boards will endeavor to protect the interests of stakeholders by completing tasks within a specified time period so that time efficiency is expected to be improved. With more frequent board meetings, the distribution of zakat can be done more quickly.

\section{CONCLUSION}

Based on the formulation of problems, hypotheses that have been proposed, analysis of research results and discussion it can be concluded that Board Size does not affect the Disbursement Efficiency. Board Size has a negative effect on Cost Efficiency, and has no effect on Time Efficiency. Professionals on Board positively affect Disbursement Efficiency, Cost Efficiency, and Time Efficiency. Frequency of Board Meetings has a positive effect on Disbursement Efficiency, a negative effect on Cost Efficiency, and a positive effect on Time Efficiency.

A suggestion for further research is to conduct a more in-depth analysis to find out the reasons why the direction of zakat governance influences the efficiency of zakat disbursement. This can be done using aqualitative approach of interviewing each member of the BAZNAS management board (Dewan Pertimbangan, Komisi Pengawas, and Badan Pelaksana) instead of just Komisi Pengawas. Researchers should then look for other indicators besides Zakat Disbursement Efficiency (ZDE) in assessing efficiency. In addition, other indicators in assessing cost efficiency, not just using Regional Government Budget
(APBD) assistance, should be searched for.

BAZNAS should pay attention to the issue of zakat governance especially in considering the number of supervisory commissions, professionals, as well as the number of meetings as a means to achieve the efficiency of zakat disbursement. The number of supervisory commissions should be kept to a limit to avoid cost inefficiency; professional composition of the supervisory committee should increase as it has an effect on the efficiency of zakat distribution, cost efficiency and efficiency of zakat disbursement; and the frequency of meetings with supervisory commissions that often lead to zakat disbursement and efficiencies will also lead to cost inefficiency.

For the government, this research can be a consideration fordetermining the management policy of Indonesia's National Zakat Board (BAZNAS) related to the number of members and member professionalism. In addition, the government needs to apply clear punishment in cases of inefficiency of zakat distribution by BAZNAS, which will cause BAZNAS to pay more attention to zakat governance.

Ummah can contribute to zakat governance by opting to vote professionals or community leaders who are competent in the field of zakat as well as to supervise BAZNAS accountability practices by looking at the efficiency of zakat distribution. In the manner of the efficient delivery of zakat, it will help the mustahiq (one of the recipient of zakat distribution) in taking their rights and getting a better life. As for muzakki, it will ensuretheir zakat funds are distributed to peopleaccording to Islamic Shari'a so they have more faith in the BAZNAS. Donors will no longer distribute their zakat directly to mustahiq but through institutions that have been given the mandate by the government to carry out the management of zakat for the welfare of the ummah. 


\section{REFERENCES}

Ahmad, I. \& Ma'in M., (2014). "The Efficiency of Collection and Distribution: Evidence from Two Stage Analysis", Journal of Economic Coorporation and Development", 35(3), pp. 133-170.

Ahmad, R.A.R. et al, (2015). "Assessing the Satisfication Level of Zakat Recipients Towards Zakat Management", Procedia Economics and Finance, 31, pp. 141-150.

Ali, N. et al, (2014). "The Effect of Corporate Governance on Capital Structure Decisions: A Case of Saudi Arabian Banking Sector", Acta Universitatis Danubius, 10(2), pp. 51-60.

Ali, N.N.H., (2015). "The Influence of Governance to Zakat Disbursement Efficiency: Empirical Evidence from Brunei Darussalam", Master Thesis, Malaysia: International Islamic University Malaysia.

Amara, N.B. \& Atia L., (2016). "Toward the Adoption of A Governance Model of Zakat Foundations: The Case of The Algerian Zakat Funds", International Journal of Business and Management Review, 4(2), pp. 104-118.

Beik, I.S. et al, (2014). "Towards an Establishment of an Efficient and Sound Zakat System", Working Group of Zakat Core Principles.

Beik, I.S., (2015). "Towards International Standard of Zakat System", Fiqh Zakat International Conference, Kuala Lumpur, Malaysia, 25-26 November 2015.

Bodjonegoro, B.P.S., (2016). "Paparan Menteri Perencanaan Pembangunan Nasional/Kepala Badan Perencanaan Pembangunan Nasional. Seminar Nasional Peran Strategis Zakat dalam Cetak Biru Ekonomi Pembangunan Indonesia", Jakarta, Indonesia, 8 Agustus 2016.
Bodroastuti, T., (2009). "Pengaruh Struktur Corporate Governance terhadap Financial Distress", ASET Jurnal Ilmu Ekonomi, 11(2).

Dohmann, E.L., (2009). "Accountability in Nursing: Six Srategies to Build and Maintain A Culture of Comittment", Marblehead: HCpro, Inc.

Doyle, L.M., (2005). "Nonprofit Board Accountability: A Literature Review and Critique", SPNA Review, 1(1), pp. 27-37.

Gobel, M., (2013). "Analisis Efisiensi Biaya Operasional Melalui Pengelolaan Tunjangan Makan dan Jaminan Pemeliharaan Kesehatan pada Perusahaan Jasa Outsourcing", Jurnal EMBA, 1(4), pp. 1868-1878.

Hafidhuddin, D., (2007). "Zakat dalam Perekonomian Modern", Jakarta: Gema Insani.

(2009). "Agar Harta Berkah dan Bertambah", Jakarta: Gema Insani.

Hosen, M.N. \& Rahmawati R., (2016). "Efficiency and Profitability on Indonesian Islamic Banking Industry", AL-IQTISHAD Journal of Islamic Economics, 8(1), pp. 3348.

Hsu, W.Y. \& Petchsakulwong P., (2010). "The Impact of Corporate Governance on the Efficiency Performance of Thai Non-Life Insurance Industry", The Ganeva Pappers, 25, pp. 28-49.

Ingram, R.T., (2015). "Ten Basic Responbilities of Nonprofit Boards", Washington: Board Source.

Jaelani, A., (2016). "Zakat Management in Indonesia and Brunei Darussalam. Munich Personal RePec Archive", 71561, pp. 1-156.

Kahf, M., (1989). "Zakat: Unresolved Issues in the Contemporary Fiqh", Journal of Islamic Economics, 2(1), pp. 1-22. 
Khanchel, I., (2007). "Corporate Governance: Measurement and Determinant Analysis", Managerial Auditing Journal, 22(8), pp. 774760.

Kholis, N. et al, (2013). "Profile of Islamic Filantrophy in Yogyakarta Special Province", Munich Personal RePec Archive, 58599, pp. 61-84.

Laela, S.F., (2010). "Analisis Faktor-faktor yang Mempengaruhi Kinerja Organisasi Pengelola Zakat", TAZKIA Islamic Finance Business Review, 5(2), pp. 126-146.

Lestari, P. et al, (2015). "Identifikasi Faktor Organisasional dalam Pengembangan E-Governance pada Organisasi Pengelola Zakat", MIMBAR, 31(1), pp. 221-228.

Lin, C. et al, (2009). "Corporate Governance and Firm Efficiency: Evidence from Chinas's Publicly Listed Firms", Managerial and Decision Economics, 30(3), pp. 193-209.

Mustaffha, N., (2007). "Zakat Disbursement Efficiency: A Comparative Study of Zakat Institutions in Malaysia", Doctor Disertassion. Malaysia: International Islamic University Malaysia.

Nikmatuniayah \& Marliyati, (2015). "Akuntabilitas Laporan Keuangan Lembaga Amil Zakat”, MIMBAR, 31(2), pp. 485-494.

Noor, A.H.M. et al, (2014). "What The Determine Professionalism? A Study on Zakat Institutions Integration Effort into The Mainstream Economy", MiddleEast Journal of Scientific Research, 27(2), pp. 983-993. , (2015). "Efficiency

of Islamic Institutions: Empirical Evidence Zakat Organizations Performances in Malaysia", Journal of Economics, Business, and Management, 3(2), pp. 282-286.
Ntim, C.G. \& Osei K.A., (2011). "The Impact of Corporate Board meetings on Coorporate Performance in South Africa", African Review of Economics and Finance, 2(2), pp. 83-103.

Nurzaman, M.S., (2010). "Zakat and Human Development: An Emprical Analyis on Poverty Alleviation in Jakarta, Indonesia", Center for Islamic Economics and Finance, Qatar Faculty of Islamic Studies, Qatar Foundation.

Oran, A.F., (2009). "Zakat Funds and Wealth Creation", Review of Islamic Economics, 13(1), pp. 143154.

Rahayu, N.W.I., (2014). "Lembaga Amil Zakat, Politik Lokal, dan Good Governance di Jember", KARSA, 22(2).

Rahman, A.R.A. (2007). "Pre-Requisites for Effective Integration of Zakat into Maistream Islamic Financial System in Malaysia", Islamic Economis Studies, 14(2).

Rahman, A.A. et al, (2012). "Zakat Institutions in Malaysia", GIAT, 2(1), pp. 35-41.

Sekaran, U., (2003). "Research Methods for Business: A Skill Building Approach", New York: John Wiley \& Sons, Inc.

Shivdasani, A. \& Zenner M., (2002). "Best Practice in Corporate Governance: What Two Decades of Research Reveals", New York: Salomon Smith Barney.

Snowdown, A. \& Rajacich, D., (1993). "The Challenge Accountabilty in Nursing", Nursing Forum, 28, pp. 5-11.

Suliyanto, (2011). "Ekonometrika Terapan: Teori dan Aplikasi dengan SPSS", Yogyakarta: Andi.

Sobana, D.S. et al, "The Variables that Affect Compliance of Muslim Merchants for Zakat Maal in the District of Cianjur", International Journal of Zakat, 1(1), pp. 78-87. 
Tomar, S. \& Bino A., (2012). “Corporate Governance and Bank Performance: Evidence from Jordanian Banking Industry", Jordan Journal of Business Administration, 8(2), pp. 353-372.

Vafeas, N., (1999). "Board Meeting Frequency and Firm Performance", Journal of Financial Economics, 53(1), pp.113-142.

Wahab, N.A., (2013). "Efficiency and Governance of Zakat Institutions in Malaysia", Doctor Dissertasion, Malaysia: International Islamic University Malaysia.

Wahab, N.A. \& Rahman A.R.A., (2011). A "Framework to Analyse Efficiency and Governance of
Zakat Institutions", Journal of Islamic Accounting and Business Research, 2(1), pp. 43-62.

Widarjono, A., (2016). "Ekonometrika Pengantar dan Aplikasinya Disertai Panduan Eviews", Yogyakarta: UPP STIM YKPN.

Novendi Arkham Mubtadi

Peradaban University

Indonesia

novendi_arkham@yahoo.co.id

Dewi Susilowati

Jenderal Soedirman University

Indonesia

dewsuslow@gmail.com 
